\title{
IDENTIFIKASI KARAKTERISTIK PENGUNJUNG DESA WISATA DI KABUPATEN BANYUMAS
}

\author{
Bambang \\ Universitas Jenderal Soedirman \\ Jl. Profesor DR. HR Boenyamin No.708, Kab. Banyumas \\ bambangunsoed2014@gmail.com
}

\begin{abstract}
The purpose of this study is to identify the characteristics of rural tourism visitors in Banyumas District through several indicators. The method of analysis in this study use descriptive statistical analysis. The analysis shows that the visitors of rural tourism in Banyumas District is dominated by young people. This is seen from most visitors are in the range of young age and still a student status. This characteristic can be used as the basis by related parties in increasing tourist visit in Banyumas Regency.
\end{abstract}

Abstrak: Tujuan penelitian ini adalah melakukan identifikasi karakteristik pengunjung desa wisata di Kabupaten Banyumas melalui beberapa indikator. Metode analisis dalam penelitian ini menggunakan analisis statistik deskriptif. Hasil analisis menunjukkan bahwa pengunjung desa wisata di Kabupaten Banyumas didominasi oleh kalangan anak muda. Hal ini terlihat dari sebagian besar pengunjung berada pada rentang usia muda, tinggal di sekitar Banyumas dan masih berstatus pelajar/ mahasiswa. Karakteristik tersebut dapat dijadikan acuan dasar oleh pihak - pihak terkait dalam meningkatkan kunjungan wisatawan di Kabupaten Banyumas.

Kata Kunci: Pengunjung, Desa Wisata, Banyumas

\section{PENDAHULUAN}

Berdasarkan karakteristik geografisnya, Kabupaten Banyumas memiliki potensi besar dalam pengembangan desa wisata. Kabupaten Banyumas merupakan daerah yang terdiri dari lembah Sungai Serayu, dataran tinggi/ pegunungan, dan hutan tropis dilereng Gunung Slamet. Hal ini menjadikan Kabupaten Banyumas sangat beragam dalam potensi desa wisata. Ditambah lagi secara aspek sosial ekonomi, letak geografis Kabupaten Banyumas di tengah-tengah lima kabupaten lainnya di Jawa Tengah (Jati et. al, 2014) juga merupakan peluang bagi pengembangan pariwisata. Akan tetapi pengembangan wisata di Kabupaten Banyumas selama ini masih berkutat pada pengembangan objek wisata secara konvensional. Pengembangan wisata di Kabupaten Banyumas hanya berbasis pada objek wisata saja tidak pada pengembangan kawasan wisata yang terintegrasi seperti desa wisata. Padahal dari 14 objek wisata utama yang ada di Kabupaten Banyumas, 11 diantaranya merupakan objek wisata alam yang menawarkan susasana pedesaan (Badan Pusat Statistik, 2015).

Potensi Kabupaten Banyumas dalam pengembangan desa wisata beriringan dengan peningkatan jumlah pengunjung objek wisata. Jumlah pengunjung objek 
wisata di Kabupaten Banyumas selalu mengalami peningkatan. Pada tahun 2009 jumlah pengunjung objek wisata di Kabupaten Banyumas adalah sebanyak 525.824 orang dan terus meningkat sampai tahun 2013 menjadi sebanyak 866.648 orang (BPS Banyumas, 2015). Peningkatan jumlah pengunjung objek wisata tersebut sayangnya tidak diikuti dengan kunjungan di masing - masing objek wisata di Kabupaten Banyumas. Jumlah pengunjung di masing - masing objek wisata hampir semuanya mengalami fluktuasi kecuali objek wisata Pancuran 3 dan Lokawisata Baturaden. Beberapa lokasi dari objek wisata tersebut cukup berdekatan, tetapi penyebaran jumlah pengunjungnya tidak terlihat sejalan.

Pengembangan desa wisata di Kabupaten Banyumas yang potensial juga dihadapkan pada beberapa permasalahan. Permasalahan tersebut diantaranya potensi kepariwisataan dan kebudayaan yang ada belum optimal diberdayakan, belum optimalnya pemanfaatan aparatur yang ada untuk pelaksanaan pengembangan kepariwisataan dan kebudayaan, sarana prasarana kepariwisataan dan kebudayaan yang tersedia belum sesuai, mekanisme kerja belum berjalan sebagaimana mestinya, dan semakin meningkatnya tuntutan wisatawan dalam pencapaian kepuasan yang diperoleh melalui perjalanan wisata (Bambang et. al, 2017). Kendala dalam pengembangan desa wisata lainnya yaitu kebijakan pengembangan wisata yang masih konvensional dimana hanya mengandalkan objek wisata tidak membangun kawasan wisata terintegrasi.

Melalui latar belakang tersebut, penelitian ini akan menganalisis desa wisata dari perspektif karakteristik pengunjungnya. Analisis desa wisata dari perspektif karaktersitik pengunjung akan menjelaskan gambaran umum kecenderungan konsumen yang selama ini memanfaatkan desa wisata. Dengan menggunakan perspektif tersebut, penelitian ini diharapkan akan menghasilkan kajian awal bagi pengembangan desa wisata. Gambaran karakteristik pengunjung akan membantu langkah pemangku kepentingan sektor pariwisata dalam membuat kebijakan yang sesuai dengan kebutuhan masyarakat/ pengunjung. Harapannya adalah pengembangan desa wisata mampu memberikan kontribusi terhadap pendapatan daerah dan pendapatan nasional (Waraditya, 2014).

\section{TINJAUAN TEORETIS}

\section{Konsep Desa Wisata}

Untuk mendefinisikan desa wisata, konsep desa dan wisata secara terpisah penting juga untuk diketahui. Menurut UU Desa Nomer 6 tahun 2014, desa diartikan sebagai kesatuan masyarakat hukum yang mempunyai batas wilayah yang berwenang untuk mengurus dan mengatur urusan pemerintahan, kepentingan masyarakat setempat berdasar prakarsa masyarakat, hak asal usul, dan/atau hak tradisional yang diakui dan dihormati dalam sistem pemerintahan Negara Kesatuan Republik Indonesia. Berdasarkan pasal 7 dalam Undang - Undang tersebut disebutkan bahwa pemerintah, pemerintah daerah provinsi, dan pemerintah daerah kabupaten/ kota bisa melakukan penataan desa berdasar hasil evaluasi tingkat perkembangan pemerintahan dan pembangunan desa. Tujuan dari penataan desa ini yaitu mewujudkan efektivitas penyelenggaraan pemerintahan desa, mengakselerasi 
peningkatan kesejahteraan masyarakat desa, mendorong peningkatan kualitas pelayanan publik, meningkatkan kualitas tata kelola pemerintahan desa, serta meningkatkan daya saing desa. Berdasarkan Undang-undang Nomer 9 Tahun 1990 tentang kepariwisataan, wisata adalah kegiatan perjalanan atau sebagian dari kegiatan perjalanan tersebut yang dilakukan dengan sukarela dan bersifat sementara yang bertujuan untuk menikmati objek dan daya tarik wisata.

Desa wisata ialah suatu bentuk integrasi antara atraksi, akomodasi, dan fasilitas pendukung yang diwujudkan dalam suatu struktur kehidupan masyarakat yang menyatu dengan tata cara, budaya, dan tradisi yang berlaku (Dewi et.al, 2013). Menurut Priasukmana dan Mulyadin (2001), desa wisata yaitu suatu kawasan perdesaan yang menawarkan suasana yang menggambarkan keaslian perdesaan baik dari kehidupan sosial ekonomi, adat istiadat, sosial budaya, keseharian, arsitektur bangunan dan struktur tata ruang desa yang khas, atau kegiatan perekonomian yang unik dan menarik serta mempunyai potensi untuk dikembangkannya berbagai komponen kepariwisataan. Kegiatan perekonomian yang unik dan khas tersebut meliputi atraksi, akomodasi, makanan-minuman, dan kebutuhan wisata lainnya. Di kawasan desa wisata, penduduk masih memiliki tradisi dan budaya yang relatif asli dan menjunjung kearifan lokal. Selain itu, faktor pendukung desa wisata seperti makanan khas daerah, sistem pertanian, sistem sosial, kondisi dan lingkungan yang masih asli menjadi salah satu faktor terpenting pada sebuah daerah tujuan wisata.

Gumelar (2010) dalam Zakaria dan Suprihardjo (2014) mengemukakan bahwa terdapat beberapa komponen dari desa wisata. Komponen desa wisata tersebut adalah memiliki keunikan, keaslian, dan atau sifat khas tertentu, letaknya berdekatan dengan daerah alam, berkaitan dengan kelompok atau masyarakat berbudaya yang secara hakiki menarik minat pengunjung, dan memiliki peluang untuk berkembang baik dari sisi prasarana, maupun sarana lainnya. Dari definisi tersebut, dapat disimpulkan bahwa desa wisata merupakan pengembangan sebuah desa yang memiliki potensi alam atau lingkungan serta kebudayaan yang memiliki potensi wisata dengan dilengkapi dengan berbagai fasilitas untuk mendukung kemajuan desa dan meningkatkan kesejahteraan serta pemberdayaan masyarakat setempat (Sari et. al, 2015).

Sebagai produk wisata alternatif, desa wisata diyakini dapat memberikan dorongan bagi pembangunan perdesaan yang terintegrasi, dan berkelanjutan serta memiliki prinsip-prinsip pengelolaan yang mendukung pembangunan desa. Prinsip - prinsip tersebut yaitu (1) memanfaatkan sarana dan prasarana masyarakat setempat, (2) menguntungkan masyarakat setempat, (3) berskala kecil untuk memudahkan terjalinnya hubungan timbal balik dengan masyarakat setempat, (4) melibatkan masyarakat setempat, (5) menerapkan pengembangan produk wisata pedesaan. Beberapa kriteria yang mendasari prinsip - prinsip pengelolaan desa wisata meliputi (Sastrayuda, 2010).

Pertama, penyediaan fasilitas dan prasarana yang dimiliki masyarakat lokal yang biasanya mendorong peran serta masyarakat dan menjamin adanya akses ke sumber fisik merupakan batu loncatan untuk berkembangnya desa wisata. Kedua, mendorong peningkatan pendapatan dari sektor pertanian dan kegiatan ekonomi tradisional lainnya. Ketiga, penduduk setempat memiliki peranan yang efektif dalam 
proses pembuatan keputusan tentang bentuk pariwisata yang memanfaatkan kawasan lingkungan dan penduduk setempat memperoleh pembagian pendapatan yang pantas dari kegiatan pariwisata. Keempat, mendorong perkembangan kewirausahaan masyarakat setempat.

\section{Penelitian Terdahulu}

Untuk melandasi kerangka berpikir, penelitian ini menelaah beberapa penelitian terdahulu sebagai acuan penelitian yang akan dilakukan. Terkait dengan desa wisata, Zakaria dan Suprihardjo (2014) mengemukakan bahwa pengembangan desa wisata dapat dilakukan dengan konsep spasial dan non spasial. Konsep spasial yaitu dengan menyediakan rute perjalanan wisata, menyediakan sarana transportasi khusus menuju kawasan desa wisata dan menyediakan fasilitas pendukung kegiatan wisata, sedangkan konsep non spasial adalah dengan menjadikan adat istiadat sebagai peraturan kegiatan wisata, mengembangkan kawasan desa wisata berbasis agrowisata, menyediakan toko souvenir, menyediakan fasilitas rumah makan, memberikan pelatihan kepada masyarakat, menyediakan tempat rekreasi, membuat web tentang kawasan desa wisata, melibatkan masyarakat dalam proses pengembangan dan menerapkan peraturan zonasi.

Ivolga dan Erokhin (2013) mengkaji suatu pendekatan kontemporer untuk memahami pembangunan berkelanjutan, peran dari pariwisata dalam menjamin pembangunan berkelanjutan di perdesaan, dan menganalisis efisiensi dari kepuasaan wisatawan dan potensi tempat rekreasi. Temuannya adalah jaminan pembangunan ekonomi yang berkelanjutan mendorong ketertarikan investasi dalam pembangunan infrastruktur rekreasi dan tempat wisata, sanatorium, resort, transportasi dan perangkat wisata lainnya. Hal yang palng penting dalam pembangunan perdesaan berkelanjutan yang berbasis pariwisata adalah efektivitas penggunaan lingkungan yang ada, cuaca, kesehatan, tempat rekreasi, dan wilayah perdesaan itu sendiri.

Torre, Fuentes, dan Hidalgo (2013) melakukan penelitian dengan mengangkat judul Rural Tourism in Natural Parks in Andalusia: An Analysis of the Demand of the Tourism Consumer. Penelitian ini mengangkat variabel sebagai berikut yaitu kepuasan konsumen, jenis kelamin, umur, tempat tinggal (desa/kota), status, pendapatan, jumlah anggota keluarga, jenis akomodasi, biaya, pendidikan, dan infrastruktur. Dengan metode penelitian yang digunakan yaitu analisis menggunakan logit, penelitian ini menemukan bahwa penawaran infrastruktur hotel tidak dapat memuaskan permintaan wisatawan. Oleh karena itu diperlukan koordinasi untuk merencanakan aktivitas desa wisata agar dapat berdampak pada perekonomian di Desa wisata tersebut.

Streimikiene dan Bilan (2015) mengungkapkan konsep desa wisata yang meliputi penyedia layanan dan konsumen, kepentingan dan harapan masyarakat setempat. Berdasarkan penelitiannya pariwisata pedesaan terintegrasi dalam ekonomi, sosial, budaya, sumberdaya manusia dan struktur lokal. Model pengembangan wisata pedesaan harus dimulai dari motivasi masyarakat setempat. Penelitian tersebut menggunakan analisis penawaran wisata, analisis teori motivasi wisata, dan framework. 


\section{METODE PENELITIAN}

Penelitian ini dilakukan di lima desa wisata di Kabupaten Banyumas yaitu Desa Ketenger, Desa Karangsalam, Desa Petahunan, Desa Tumiyang, dan Desa Tambaknegara Kabupaten Banyumas. Pendekatan yang digunakan dalam penelitian ini adalah pendekatan kuantitatif. Pendekatan kuantitatif yang digunakan dalam penelitian adalah analisis statistik deskriptif. Statistika deskriptif merupakan metode analisis yang berkaitan dengan pengumpulan dan penyajian suatu data sehingga memberikan informasi yang bermanfaat (Walpole, 1993). Dengan Statistika deskriptif, kumpulan data yang diperoleh akan tersaji dengan ringkas dan rapi serta dapat memberikan informasi inti dari kumpulan data yang ada. Informasi yang dapat diperoleh dari statistika deskriptif ini antara lain ukuran pemusatan data, ukuran penyebaran data, serta kecenderungan suatu gugus data.

Data yang digunakan dalam penelitian ini adalah data primer. Data primer diperoleh langsung dari responden melalui teknik wawancara secara mendalam dengan responden. Responden yang diwawancarai didapatkan melalui teknik accidental sampling. Teknik accidental sampling merupakan teknik sampling dimana sampel dipilih secara sembarang (kapanpun dan dimanapun menemukan) asal memenuhi syarat sebagai sampel dari populasi tertentu. Sampel dalam penelitian ini merupakan pengunjung yang ditemui di lokasi penelitian secara tidak sengaja dan direncanakan. Jumlah sampel yang diambil dalam penelitian ini adalah sebanyak 100 responden.

\section{PEMBAHASAN}

\section{Karakteristik Umur Pengunjung}

Umur pengunjung obyek wisata di desa wisata Banyumas berkisar antara 12 tahun sampai 70 tahun dengan rata-rata pengunjung berumur 20 tahun. Hal ini menunjukkan bahwa desa wisata cukup dinikmati oleh pengunjung dari usia muda sampai dengan dewasa. Pengunjung objek wisata mayoritas adalah usia muda dengan rentang umur 12-24 tahun dengan persentase sebesar $47 \%$. Berdasarkan rentang usia tersebut, promosi dan arah pengembangan desa wisata sebaiknya disesuaikan dengan kecenderungan minat anak muda.

Gambar 1. Usia Pengunjung

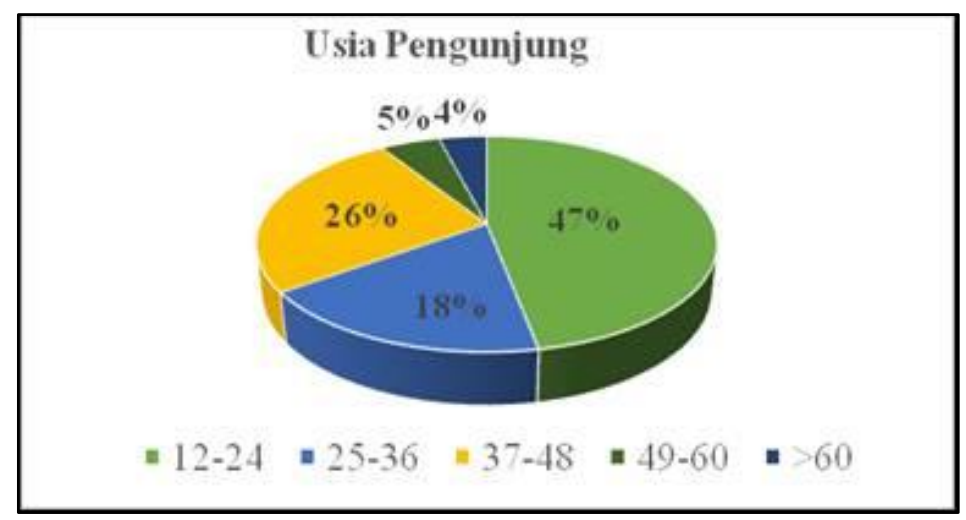




\section{Karakteristik Jenis Kelamin Pengunjung}

Karakteristik pengunjung desa wisata berikutnya dapat dilihat berdasarkan jenis kelamin. Jenis kelamin pengunjung desa wisata di Kabupaten Banyumas relatif berimbang walaupun jenis kelamin pengunjung desa wisata di Banyumas adalah lebih banyak laki - laki. Proporsi jenis kelamin responden pengunjung desa wisata adalah responden laki-laki sebanyak $57 \%$ dan responden perempuan sebesar $43 \%$. Hal ini dapat terjadi mengingat sebagian besar pengunjung desa wisata datang dengan pasangan atau teman - temannya.

\section{Gambar 2. Proporsi Jenis Kelamin Pengunjung}

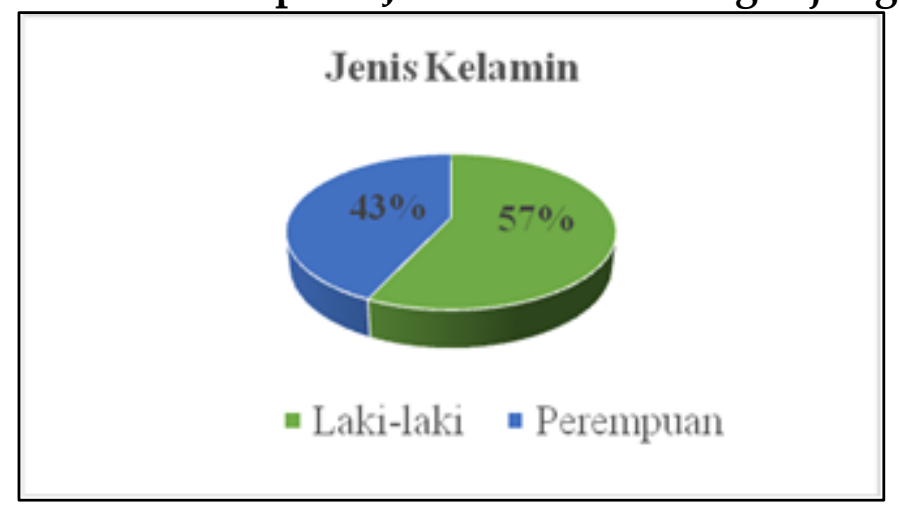

\section{Karakteristik Status Marital Pengunjung}

Hampir sama dengan kondisi pengunjung berdasarkan dengan jenis kelamin, status marital pengunjung desa wisata di Kabupaten Banyumas juga hampir berimbang. Proporsi status marital pengunjung objek wisata adalah reponden yang belum menikah sebesar $55 \%$ dan yang sudah menikah sebesar $45 \%$.

\section{Gambar 3. Proporsi Status Marital Pengunjung}

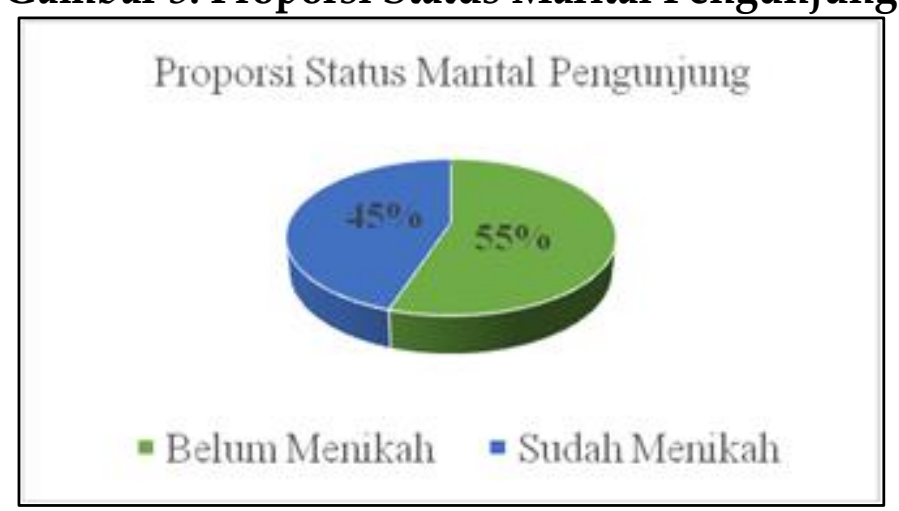

\section{Karakteristik Pendidikan Pengunjung}

Tingkat pendidikan yang sedang ditempuh para pengunjung obyek wisata berkisar antara 9 tahun dan 17 tahun. Angka pendidikan diperoleh dari tahun lamanya responden menempuh pendidikan formal dimulai dari pendidikan Sekolah Dasar. Pengunjung terbesar berasal dari anak-anak remaja Sekolah Menengah Atas dengan persentase sebesar $37 \%$. Kemudian disusul oleh kalangan mahasiswa dengan persentase sebesar 30\%. Tingginya tingkat pendidikan pengunjung di desa wisata 
Kabupaten Banyumas mengindikasikan bahwa kebutuhan akan rekreasi sudah menjadi focus bagi kalangan masayarakat dengan pendidikan tinggi.

\section{Gambar 4. Proporsi Pendidikan Pengunjung}

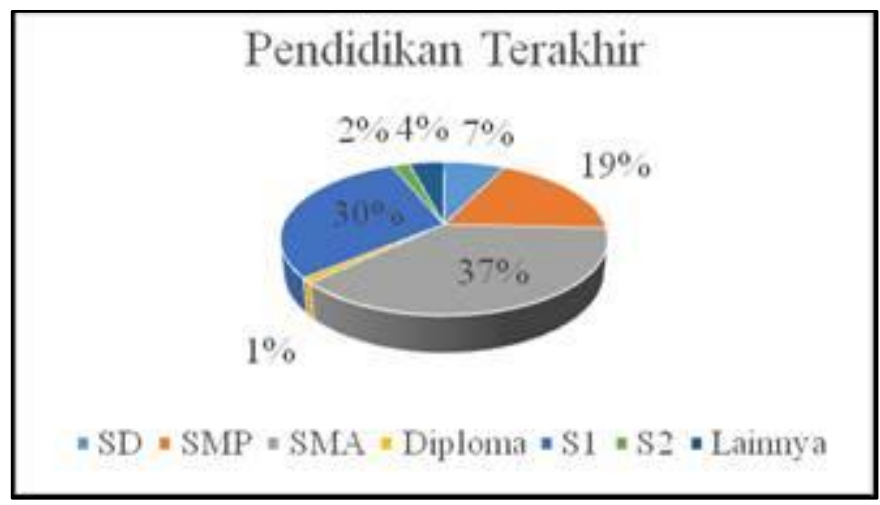

\section{Karakteristik Pekerjaan Responden}

Jenis pekerjaan pengunjung desa wisata dapat menjadi indikator penting dalam menunjukkan pengembangan desa wisata dari sisi konsumen. Pengunjung yang datang ke objek wisata sebagian besar adalah pelajar/mahasiswa, yaitu sebesar $37 \%$. Lalu persentase terbesar kedua sebesar $24 \%$ adalah jenis pekerjaan swasta. Responden yang bekerja sebagai wiraswasta sebesar $16 \%$ dan pengunjung yang bekerja sebagai PNS sebesar 4\%. Harga tiket masuk yang murah dan lokasi yang dapat dijangkau dengan mudah menjadi alasan tersendiri kenapa kalangan pelajar/ mahasiswa dan pekerja swasta memilih berkunjung di desa wisata.

\section{Gambar 5. Jenis Pekerjaan Pengunjung}

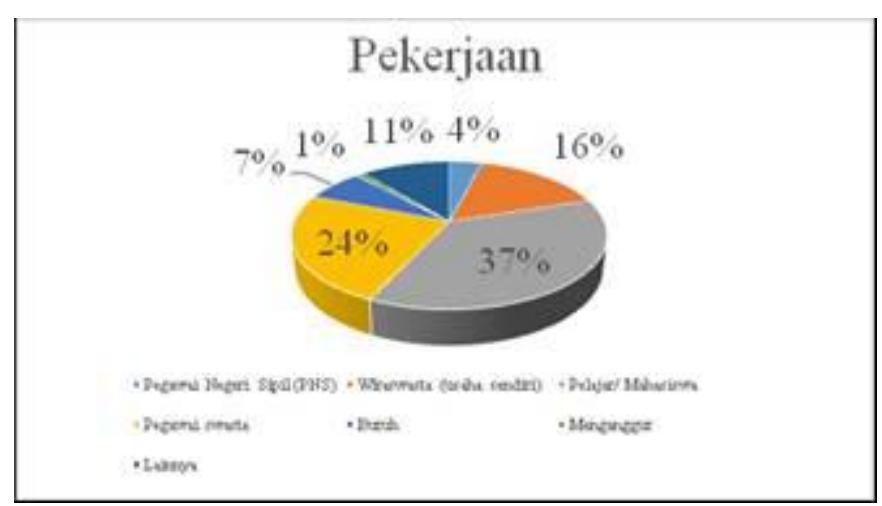

\section{Karakteristik Penghasilan (uang saku) per Bulan Responden}

Perbedaan karakteristik pengunjung desa wisata berdasarkan latar belakang pendidikan dan jenis pekerjaan berdampak pada karakteristik penghasilan pengunjung desa wisata di Kabupaten Banyumas. Dari 100 responden yang diperoleh, dapat diketahui bahwa penghasilan pengunjung obyek wisata berkisar antara Rp 60.000,- sampai dengan Rp 15.000.000,- dan rata-ratanya sebesar Rp 
2.386.173,-- Hal ini menunjukkan bahwa pengunjung obyek wisata mempunyai penghasilan yang cukup bervariasi.

\section{Gambar 6. Distribusi Pendapatan atau Uang Saku Pengunjung}

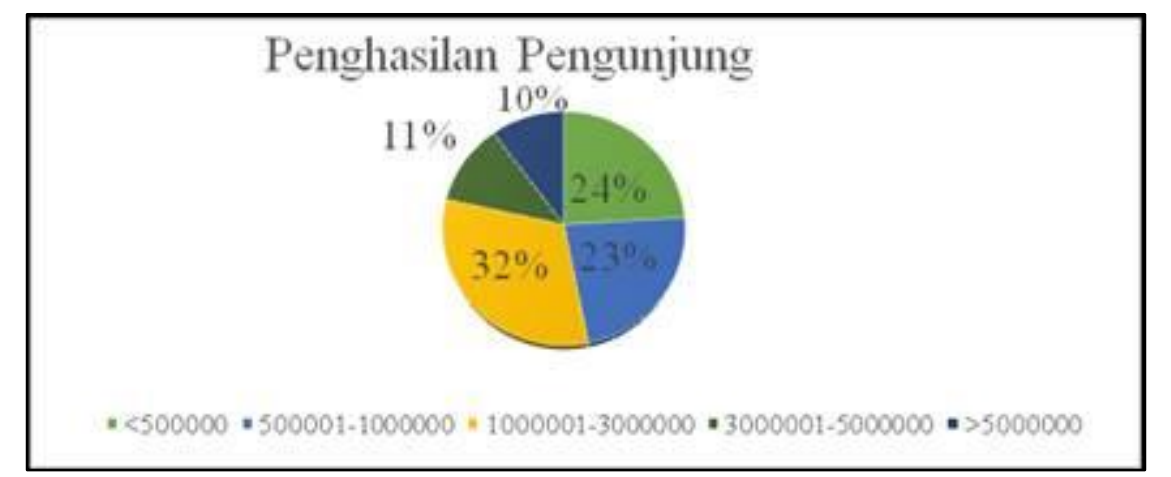

\section{Karakteristik Tujuan Berwisata Responden}

Kebutuhan dan arti penting berekreasi terlihat pada tujuan berwisata responden. Sebanyak 70\% responden dari keseluruhan sampel datang ke objek wisata dengan tujuan untuk berekreasi. Sementara $16 \%$ responden datang dengan tujuan Lainnya. Sisanya sebesar $14 \%$ datang karena diajak teman.

\section{Gambar 7. Motivasi Pengunjung Berkunjung}

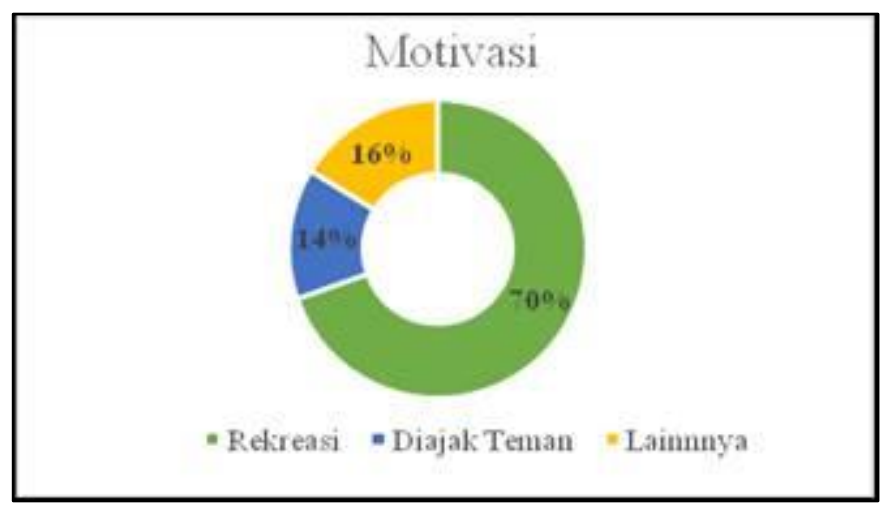

\section{Karakteristik Kelompok Kunjungan}

Karakteristik pengunjung yang datang lebih banyak berkelompok dapat dilihat pada Gambar 8. Sebanyak 68\% dari sampel yang diambil, pengunjung desa wisata datang bersama teman/rombongan., sedangkan sebanyak 23\% datang bersama keluarga dan sebanyak $9 \%$ datang sendirian. Hal ini mengindikasikan bahwa efektifitas promosi wisata dapat memiliki dampak multiplier terhadap jumlah kunjungan. Satu orang yang tertarik berkunjung dapat mempengaruhi temannya atau orang lain untuk bersama - sama mendatani desa wisata. 


\section{Gambar 8. Kelompok Kunjungan Wisata ke Desa Wisata}

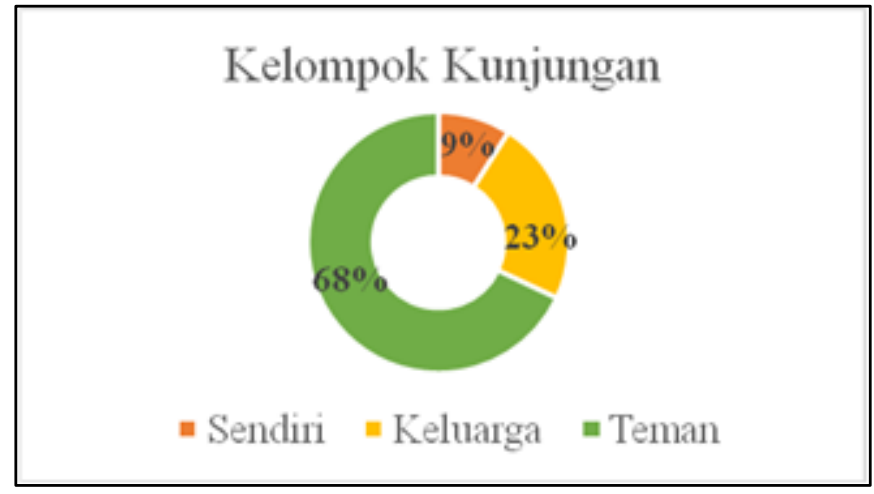

\section{Karakteristik Transportasi yang Digunakan Responden}

Oleh karena lokasi yang mudah dijangkau dan sebagian besar adalah anak muda, kendaraan pribadi merupakan pilihan utama pengunjung untuk mendatangi desa wisata. Sebagian besar pengunjung menggunakan sepeda motor (pribadi) untuk sampai ke objek wisata, yaitu sebesar $84 \%$. Pengunjung yang datang dan pergi menggunakan kendaraan pribadi berupa mobil sebesar $14 \%$. Sisanya, sebesar $2 \%$ pengunjung menggunakan angkutan umum untuk mencapai lokasi.

\section{Gambar 9. Jenis Tranportasi yang Digunakan Pengunjung}

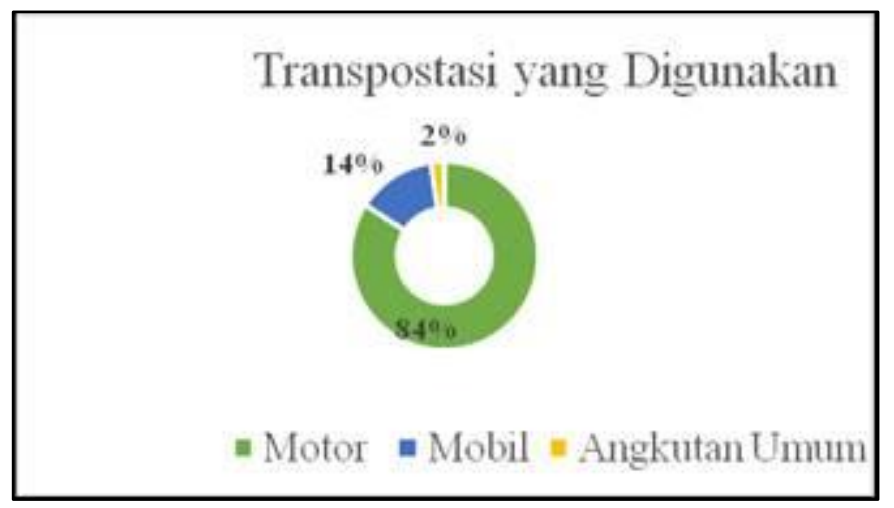

\section{Karakteristik Lama Kunjungan Responden}

Berdasarkan Gambar 11 dapat diketahui bahwa mayoritas pengunjung, yaitu sebesar $94 \%$ tidak menginap saat melakukan kunjungan ke desa wisata. Hal ini mengindikasikan bahwa mayoritas pengunjung berasal dari sekitar Kabupaten Banyumas. Hanya 6\% responden yang menginap saat melakukan kunjungan ke desa wisata. Tempat yang dipilih responden untuk menginap adalah hotel dan atau guest house. 
Gambar 11. Inapan Pengunjung

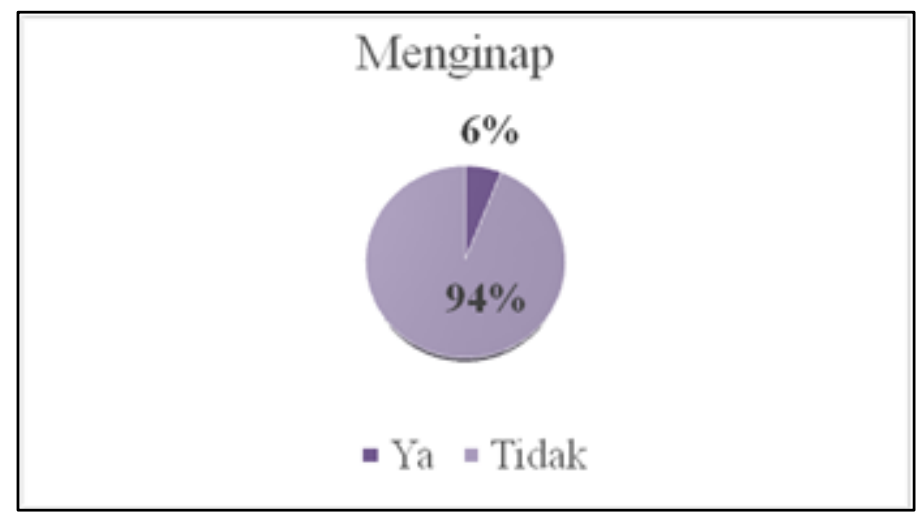

\section{Karaktersitik Aktivitas yang Disukai Pengunjung}

Pemandangan alam yang indah masih menjadi daya tarik bagi desa wisata di Kabupaten Banyumas. Dari seluruh responden pengunjung desa wisata, sebanyak $68 \%$ pengunjung suka melihat pemandangan yang ada di tempat wisata. Kegiatan atau hal lain sebesar 14\% yang disukai responden, yaitu memancing, jalan-jalan, serta menikmati kulinernya. Kemudian sebanyak $12 \%$ responden suka untuk berenang di lokasi wisata. Sementara sisanya, yaitu sebesar $4 \%$ lebih suka untuk bermain wahana yang ada di desa wisata.

\section{Gambar 12 Aktivitas yang Disukai Pengunjung}

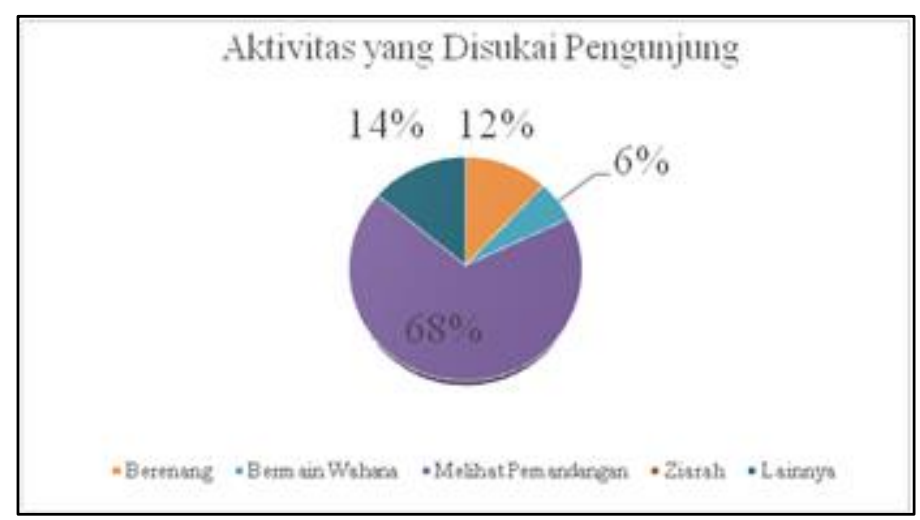

\section{Keinginan untuk Datang Kembali}

Daya tarik desa wisata bagi pengunjung dapat meninggalkan kesan yang mendalam. Hal ini terbukti dari keinginan untuk datang kembali ke desa wisata. Sebanyak $92 \%$ responden pada umumnya ingin datang kembali ke desa wisata sedangkan $8 \%$ menyatakan tidak ingin datang kembali lagi.

\section{Karaktersitik Wisata yang Paling Disukai Pengunjung}

Dengan sebagian besar menawarkan panorama alam, keberadaan desa wisata dipandang tepat bagi kebutuhan pengunjung. Hal ini terbukti dari preferensi pengunjung yang menyukai wisata alam dan pegunungan. Dari Gambar 14 dapat diketahui bahwa wisata pegunungan merupakan wisata yang paling disukai oleh responden, yaitu sebesar $66 \%$. Selanjutnya bentuk wisata berupa curug, danau, dan 
kolam renang menjadi pilihan kedua responden, yaitu sebesar 19\%. Sisanya, sebesar $15 \%$ responden lebih menyukai wisata bahari.

\section{Gambar 14. Wisata yang paling Disukai}

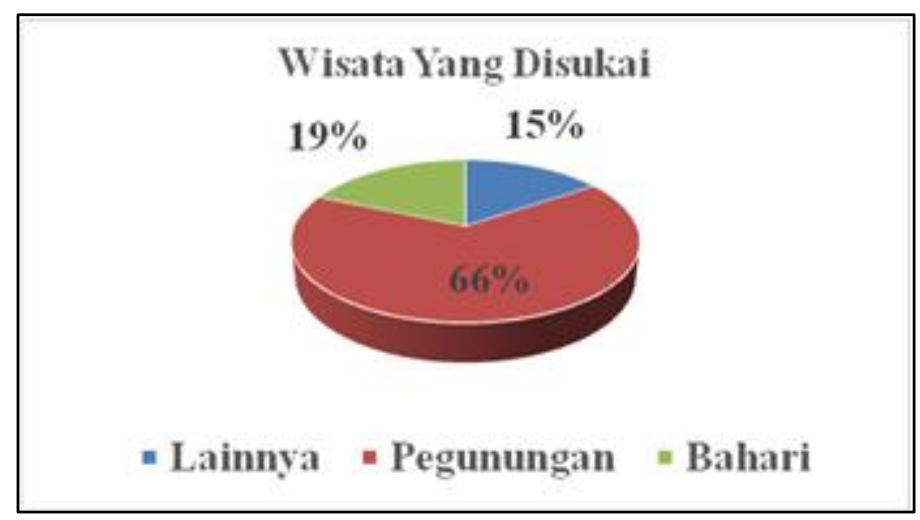

\section{Tingkat Kepuasan Pengunjung}

Berdasarkan Gambar 15 dapat diketahui bahwa mayoritas pengunjung merasa cukup puas, yaitu sebesar $46 \%$. Sebanyak $37 \%$ pengunjung menyatakan puas, $10 \%$ menyatakan kurang puas, $6 \%$ menyatakan sangat puas dan $1 \%$ menyatakan tidak puas atas kunjungan ke objek wisata.

\section{Gambar 15. Tingkat Kepuasan Pengunjung}

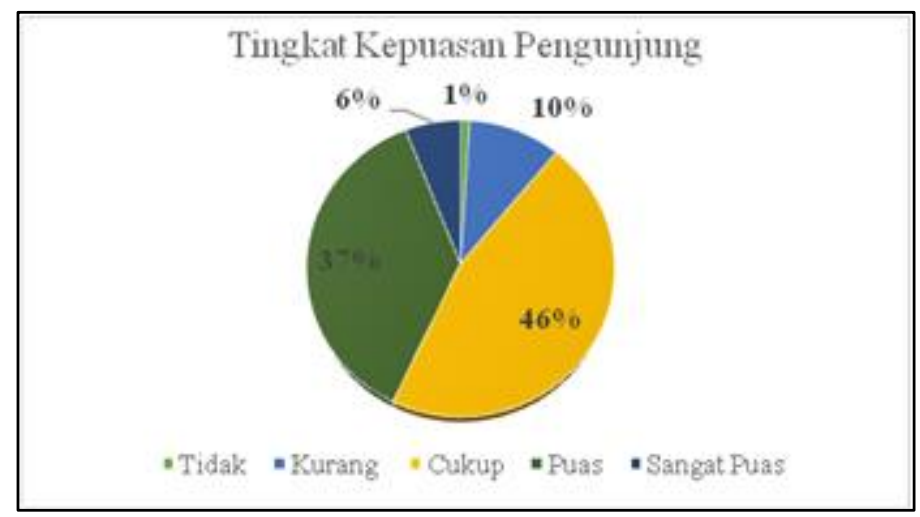

\section{PENUTUP}

Berdasarkan hasil analisis, hasil penelitian ini dapat disimpulkam bahwa mayoritas pengunjung berada pada usia muda yaitu rentang umur 12-24 dan masih berstatus sebagai pelajar/ mahasiswa. Hal ini berdampak pada status marital yang mayoritas belum menikah, menggunakan moda transportasi pribadi berupa motor, dan datang bersama teman/ rombongan dengan tujuan hanya untuk berekreasi serta mayoritas pengunjung tidak menginap. Karakteristik lainnya adalah proporsi jenis kelamin pengunjung desa wisata yang cukup berimbang dan penghasilan pengunjung cukup bervariasi. Pemandangan yang yang indah di tempat wisata 
membuat sebagian besar responden pada umumnya ingin datang kembali ke desa wisata dan menyatakan cukup puas dengan kualitas objek wisata di desa wisata.

Dengan melihat karakteristik pengunjung desa wisata tersebut, pemerintah daerah diharapkan dapat menyasar konsumen usia muda sebagai target utama pengunjung desa wisata. Hal ini dapat dilakukan dengan mengoptimalkan promosi melalui media sosial yang notabene sangat bersentuahn dengan anak muda. Walaupun sebagian besar ingin kembali berkunjung, kepuasan pengunjung yang hanya pada level cukup puas membuktikan masih perlunya perbaikan kualitas desa wisata. Keterlibatan akademisi, swasta, dan masyarakat sekitar desa wisata sangat diperlukan agar pengembangan desa wisata menjadi lebih baik.

\section{DAFTAR PUSTAKA}

Badan Pusat Statistik. 2015. Banyaknya Pengunjung Objek Wisata di Wilayah kabupaten Banyumas Tahun 2009-2013. Online. (https://banyumaskab.bps.go.id/link TabelStatis/view/id/59\#accordiondaftar-subjek3, diakses tanggal 25 Oktober 2016).

Bambang, Chandra Suparno, dan Lina Rifda Naufalin. 2017. “Kajian Desa Wisata dan Permintaannya Di Kabupaten Banyumas". Laporan Akhir Penelitian Peningkatan Kompetensi LPPM UNSOED. Tidak Dipublikasikan.

Dewi, Made Heny Urmila, Chafid Fandeli, dan M. Baiquni. 2013. "Pengembangan Desa Wisata Berbasis Partisipasi Masyarakat Lokal Di Desa Wisata Jatiluwih Tabanan, Bali". Jurnal Kawistara. Vol. 3 No. 2 Agustus 2013.

Ivolga, Anna dan Vasily Erokhin. 2013. “Tourism as An Approach to Sustainable Rural Development: Case Of Southern Russia". Economics of Agriculture. Vol. 4. Hal. 48-44.

Jati, Dian Purnomo, Agus Suroso, dan Lusi Suwandari. 2014. “Analisis kelayakan Desa Kalisari sebagai desa Wisata: Aspek Sosial Ekonomi, Operasional dan Pemasaran". Jurnal Fakultas Ekonomika dan Bisnis Unversitas Kristen Satya Wacana.

Priasukmana, Soetarso dan R. Mohamad Mulyadin. 2001. “Pembangunan Desa Wisata: Pelaksanaan Undang-Undang Otonomi Daerah". Jurnal Info Sosial Ekonomi. Vol. 2 No.1 (2001) pp. 37 - 44.

Sastrayudha, Gumelar. 2010. "Strategi Pengembangan dan Pengelolaan Resort dan Leisure". Online. (http://www.jurnal.triatmulya.ac.id/index.php /JMPII/view/12/13, tanggal 27 Oktober 2016).

Sari, Ayu Multika, Andy Fefta Wijaya, Abdul Wachid. 2015. “Penerapan Konsep Green Economy dalam Pengembangan Desa Wisata sebagai Upaya Mewujudkan Pembangunan Berwawasan Lingkungan (Studi pada Dusun Kungkuk, Desa Punten Kota Batu)" Jurnal Administrasi Publik (JAP), Vol. 2, No.4, Hal. 765-770.

Streimikiene, D. dan Y. Bilan. 2015. Review of Rural Tourism Development Theories.Transformations in Business \& Economics, Vol. 14, No 2 (35), pp.21-34.

Torre, M Genovena Millan Vazques de la, Juan Manuel Arjona Fuentes, dan Luis Amador Hidalgo. 2013. Rural Tourism in Natural Parks in Andalusia: An Analysis 
of the Demand of the Tourism Consumer. International Journal of Humanities and Social Science, Vol.3 No.1.

Undang-Undang Republik Indonesia Nomor 9 Tahun 1990 Tentang Kepariwisataan. Undang-Undang Republik Indonesia Nomor 22 Tahun 1999 Tentang Pemerintahan Daerah.

Undang-undang Republik Indonesia No. 62014 tentang Desa.

Waraditya, Dimas dan Fajar Sidik. 2014. Pertumbuhan Ekonomo: peran Industri Pariwisata Semakin Penting. Online. (http://industri.bisnis.com/read /20140521/12/229874/pertumbuhan-ekonomi-peran-industri-pariwisatasemakin-penting, diakses 23 Oktober 2016).

Walpole, Ronald E. 1993. Pengantar Statistik,. Jakarta: PT Gramedia Pustaka Utama. Zakaria, Faris dan Rima Dewi Suprihardjo. 2014. "Konsep Pengembangan Kawasan Desa Wisata di Desa Bandungan Kecamatan Pakong Kabupaten Pamekasan". Jurnal Teknik Pomits. Vol. 3, No.2, (2014) 2337-3520. 